\title{
Business practices in corporations of radio and television cable distribution programmes in Serbia*
}

\author{
Vladimir Radenković**
}

The legal and regulatory framework for business operation of companies for the cable distribution of radio and television programmes has been established as part of the telecommunication market liberalisation in the Republic of Serbia. This framework has encouraged the economic activity, demonstrating, however, certain weaknesses, primarily in respect of providing the service quality and consumer protection. Efficient operation of cable distribution systems is creating opportunities for regional cooperation in the overall sphere of telecommunications. Therefore, it needs to be addressed with adequate attention.

Im Rahmen der Liberalisierung des Telekommunikationsmarktes in der Republik Serbien ist ein rechtlicher Regelungsrahmen für unternehmensübergreifende Geschäftsprozesse für die Verbreitung von Radio-und Fernseh-Programmen via Kabel erstellt worden. Dieser Rahmen hat die Geschäftsaktivitäten gefördert, aber auch gewisse Schwachpunkte, vor allem hinsichtlich der Sicherstellung der Dienstleistungsqualität und des Verbraucherschutzes aufgezeigt. Ein erfolgreicher Betrieb von Kabelvertriebssystemen eröffnet Möglichkeiten zur regionalen Zusammenarbeit auf dem gesamten Gebiet der Telekommunikation, so dass ihm eine entsprechende Aufmerksamkeit geschenkt werden muss.

Keywords: cable distribution system, business operation, media, radio and television programmes

* Manuscript received: 13.01.10, accepted: 14.04 .10 (2 revisions)

** Vladimir Radenković, Ph.D., Assistant Prof., Department of Industrial Engineering and Management, University of Novi Sad, Serbia. Main research interests: Media management. Corresponding address: urftn@uns.ac.rs. 


\section{Introduction}

The Cable Distribution System (Cable Distribution Systems - CDS) was established as an upgrade of the broadcasting system, whose main purpose is to provide radio and television programme distribution services.

Technology development has facilitated the introduction of new services, enabling the modern CDS to grow into a multi-service, broadband telecommunication network. Apart from television and radio programme distribution, this network is providing a great number of different interactive services nowadays. For this reason the cable distribution system should be considered as part of the overall telecommunications sector.

In the mid 90s, countries of Eastern Europe entered the transition process by transforming the state-owned economy towards the model of market economy. The liberalisation of telecommunication market in Serbia has provided free access to networks and means, including the establishment of rules on fair competition. It was intended to encourage the fulfilment of public interest through the increased efficiency of operators, provide new and improve the existing services and create opportunities for further development of this field.

However, the free market in the field of radio and television programme distribution has had some undesired results, in addition to positive ones.

The analysis given in the text below will demonstrate that the regulatory framework has encouraged the business operation of cable distributors and their media integration with countries in the region of Eastern Europe, but has also ignored the users' interest, particularly in terms of service quality and consumers' rights.

\section{Legal foundation}

Telecommunications is an economic sector in which the value and scope of business operation is constantly on the increase. The indirect impact of telecommunications on the economy is most important for the society as a whole. This impact is reflected in the reduction of business operating costs, contributing to increasing the competitive ability, as well as creating new modes of performing existing economic activities and/or launching new ones.

A liberalised market is one that brings forth the aforementioned advantages. Service providers are free to appear in the market and offer their services, whereas consumers have a right to choose. Market opening is achieved through:

- demonopolisation and

- deregulation

A demonopolised market provides an opportunity for anyone who has met the technical prerequisites, to commence commercial activity at the same time 
observing the established rules applicable to all. Deregulation is the establishment of new regulations and constitution of new authorities for their enforcement.

Liberalisation of the European telecommunication market was initiated by the general integration of the European Union markets. It began by establishing harmonisation and setting up the structural funds to support common development programmes and their position in the international telecommunication market. The follow up of this process was directed towards the elimination of monopoly and introduction of competition in the market which had previously been a closed one.

The European Commission 1990 Directive 90/388/EEC set up the baseline rules in the field of telecommunications:

1. Regulatory authorities should be independent of operators and other state bodies;

2. All operators, both incumbent and new entrants, should keep to the minimum rules and standards created to prevent damage to the network, electrical hazards, privacy violations, etc;

3. Operators with a significant market power have greater and more demanding obligations than new entrants, because they need to offer a harmonised service package to customers, service providers, and other operators. They also have to offer interconnectivity and access to telecommunications networks under non-discriminatory conditions and at cost-based prices.

4. Guarantee of the set of basic rights for electronic communications service users, as well as privacy protection.

Following the European Union model, all countries of the region have started the harmonisation of their regulations. The telecommunication market liberalisation process in the countries of the region was launched in the field of data transmission, mobile telephony the Internet, cable and satellite television. Adoption of the Law on Telecommunication and establishment of independent regulatory bodies constitute and integral part of this process.

By signing the Stabilisation and Association Agreement (2008), the Republic of Serbia committed to gradually harmonise its legislation with the European Union.

\section{Background literature}

The literature used for the purpose of this analysis included the following laws and regulations: 


\section{Law on Telecommunications ${ }^{1}$}

The beginning of liberalisation and the end of monopoly in the telecommunications sector has been initiated by the Law on Telecommunications. In accordance with the international legal standards, this law regulates the terms and conditions and manner of performing the activity in the field of telecommunications. Accordingly, the Republic Telecommunications Agency should be established; competences for regulation of relations in the field of telecommunications should be established; issues shall be regulated pertaining to the following: prevention of monopoly and monopolistic behaviour; principles and procedure for awarding business licences; regulation and control of telecommunication service tariffs; interconnection of telecommunication networks and operators; lease of lines; scope, contents and improvement of universal broadcasting services, as well as the rights and duties of telecommunication operators in this field.

The Republic Telecommunications Agency (RATEL) was established in 2005 and was a prerequisite for implementation of the regulation stipulated in this law.

\section{Law on Broadcasting ${ }^{2}$}

The primary purpose of this law is to regulate the contents of the programme provided by cable and other broadcasters. In order to provide the conditions required for the efficient implementation and improvement of the established broadcasting policy in the Republic of Serbia, in a manner appropriate for a democratic society, the Republic Broadcasting Agency (RRA) should be established as independent, i.e. autonomous organisation performing public powers, in accordance with this law and regulations enacted on the basis of this law.

The Agency should be an independent legal entity and functionally autonomous from any public body, as well as from any organisation and person dealing with the radio and television programme production and broadcasting and/or other related activities.

Telecommunications Development Strategy in the Republic of Serbia from 2006 to 2010

This Strategy was adopted in 2006 by the Government of the Republic of Serbia. It is primarily focused on the development of telecommunication infrastructure and services through a consistent application of the Law on Telecommunications. It also concerns, improvement of the regulatory framework comprising the harmonisation with the regulatory framework of the

\footnotetext{
1 Official Gazette of The Republic of Serbia, no. 44/03.

2 Official Gazette of The Republic of Serbia, no. 42/02
} 
European Union and Acquis Communautaire, as well as establishing the environment for increased investments and foreign capital inflow. During the Strategy adoption process, the competition had already been permitted in CDS services. However, more that $80 \%$ of the CDS operators mainly dealt with coaxial networks, whose characteristics allowed the distribution of radio and television signals only, excluding the Internet and other modern services.

\section{Law on Planning and Construction}

Construction conditions required for installation of the CDS network are regulated in the Law on Planning and Construction (2009, Article 110) ${ }^{3}$, which is to result in the adoption of urban plans required for obtainment of the planning approval and building permits.

Urban plans envisage that cable distribution system networks should be installed under the ground, wherever feasible, immediately next to the telephone network route or along the same routes, if agreed by the owners of both networks. If the conditions required for the underground installation by the optical cable are not provided, a temporary network may be installed on the existing low voltage electric lines, telephone lines, or placed on the supports on roofs of buildings, requiring an the owner's approval.

However, when issuing the work licence to the existing operators, the current situation found on site has to be accepted. Consequently, in a number of small towns in Serbia, the cable installation has been installed over roofs, from one building to another, thus failing to comply with either building or technical standards. Such installations were set up at the time when there was no legal regulation governing this field.

\section{Rules on Issuance of Technical Licences - Certificates}

Clear and precise technical standards were adopted by the Republic Telecommunications Agency. The Rules on Issuance of Technical Licences Certificates provide a precise method for harmonisation of projects and project documentation with the established standards and norms required for telecommunication networks and systems.

Rules on Terms and Conditions for Radio and Television Programme Distribution and Contents of the Authorisation.

These rules establishe the terms and conditions necessary for the radio and television programme distribution services provision through a cable distribution network, and stipulate the form, manner of issuance of the authorisation and its contents.

3 Official Gazette of The Republic of Serbia, 2009/72. 


\section{Business operation and media integration}

\section{Business Operation of Cable Distributors}

Generally, cable operators run their business successfully. Until 2009, seventytwo cable operators have obtained the work licence in the Republic of Serbia. The total of 58 out of 72 cable companies submitted their business reports for 2008 to the Business Registers Agency and there were only three companies operating with losses. The majority of distributors (53 of them) are small enterprises, whereas 38 licenced distributors (64\%) operate with less than ten employees. On the other hand, the leading five companies cover $86 \%$ of the market and the percentage of their contribution is as follows:

- SBB (Serbia Broadband) - $54 \%$;

- JP PTT - RJ KDS - $11 \%$,

- Kopernikus technology d. o. o. $-8 \%$,

- IKOM d. o. o. $-7 \%$,

- Radijus vektor d. o. o. $-4 \%{ }^{4}$

The main activity of these companies is radio and television programme distribution service provision. They collect a monthly fee for this service from their subscribers, which constitutes the greatest part of their profit. The total profit earned by operators for radio and television programme distribution service provision increased by $49 \%$ in 2008 , when compared to the previous year, amounting approximately to 56 million EUR. This increase is primarily the result of a growing number of subscribers, as well as the rise in prices of radio and television programme distribution services (Table 1).

Table 1. Profit from subscription to the cable radio and television distribution (in million EUR)

\begin{tabular}{|c|c|c|c|c|}
\hline Year & 2005 & 2006 & 2007 & 2008 \\
\hline Profit & 17.927 & 19.00 & 37.772 & 56.325 \\
\hline
\end{tabular}

Source RATEL (Republic Telecommunications Agency). 2009. Review of telecommunication market in the Republic of Serbia in 2008

Operative costs of the CDS include the annual expenditures for the transmission and distribution rights, total costs of maintenance and investment costs (Table 2).

4 RATEL (Republic Telecommunications Agency). 2009. Review of telecommunication market in the Republic of Serbia in 2008, p 90 
Table 2. Division of costs of cable distributors (in \%)

\begin{tabular}{|c|c|c|}
\hline YEAR & 2007 & 2008 \\
\hline Distribution rights & $27 \%$ & $44 \%$ \\
\hline Maintenance costs & $8 \%$ & $10 \%$ \\
\hline Investment costs & $65 \%$ & $46 \%$ \\
\hline
\end{tabular}

Source RATEL (Republic Telecommunications Agency), 2009

The growing trend related to the costs of distribution rights is the result of a better choice of programmes and increased price for rebroadcasting of certain channels. Costs of copyrights, related rights and redistribution rights reached approximately 15 million EUR and were higher by $80 \%$ in 2008 when compared to 2007 , while maintenance costs were higher by $50 \%$, amounting to 4.5 million EUR in 2008. Total investments in the distribution of radio and television programmes were reduced by approximately $20 \%$ in 2008 , amounting to 19.7 million EUR.

There is no precise information on the number of cable distribution subscribers, due to the fact that this number has a constantly growing tendency and operators are often reluctant to provide exact information concerning the number of consumers they have as the amount of costs they have to pay for the purpose of copyright protection will depend on this number. In 2008, there were over 922,000 registered subscribers in Serbia. Penetration was 12\% when compared to the previous year (Table 3), i.e. $37 \%$ if measured by the number of households. According to the information provided by the Statistical Office of the Republic of Serbia, the average household has three members, as a result of which the number of potential cable television users is estimated to be 2.7 million.

Table 3. Number of CDS subscribers (in thousands)

\begin{tabular}{|c|c|c|c|c|c|}
\hline Year & 2005 & 2006 & 2007 & 2008 & 2009 \\
\hline Number of subscribers & 531 & 542 & 774 & 856 & 922 \\
\hline Penetration (\%) & 7 & 7 & 10 & 10 & 12 \\
\hline
\end{tabular}

Source RATEL (Republic Telecommunications Agency), (24/4/2009) Activities Report for the period 2005 to 2009

The struggle for subscribers and an increasingly better choice of programmes is, however, not accompanied by the adequate level of investments in the reconstruction of the cable network. Consequently, it may be assumed that, in the near future, consumers will not be provided with new services, such as fixed network, video conferences, telemonitoring, tele education etc. 


\section{Media integration}

Operation of cable distribution of radio and television programmes in Serbia is also relevant for countries of the region of Eastern Europe where Serbia is located, predominantly because of the media integration. The SBB company is the largest operator providing digital and analogue cable television and broadband Internet in Serbia and is, at the same time, the most significant satellite television operator in the region, present in six countries with its Total TV platform. The European fund Mid Europa based in London and European Bank for Reconstruction and Development (EBRD) have had the majority ownership of the company since 2007. It cooperates with Telemach from Slovenia, sharing the same majority owner and President of Management Board. Presence of such a large number of operators in the media creates the possibilities for developing regional cooperation in the overall sphere of telecommunications. Within its choice of programmes and in the field of cable distribution, the SBB company rebroadcasts ten channels from five countries of the region. In 2009, only the programmes from former Yugoslavian republics participated in the total viewership by $10 \%$. Due to the diverse national composition of the population of Serbia, particularly its Autonomous Province of Vojvodina, inhabited by almost all ethnic communities from the region, there is a great need to provide them with an opportunity to listen to the radio and watch television shows originating from their native countries.

\section{Consumer satisfaction}

\section{Service Prices}

Non-transparent business operation of cable distributors often leads to consumers having doubts over the legitimacy of the subscription fee amount. Information on the costs of foreign channel rebroadcasting rights remains confidential to the public. It is a known fact that the price of CDS services depends on the number of subscribers, including the obviously great disparity in prices for certain channels. Unofficially, this price ranges from 2 to 30 eurocents per subscriber per month.

Such a great disparity in prices required for rebroadcasting of certain channels provides operators with considerable possibilities for manipulation. Replacement of only one expensive programme, priced 30 euro-cent, by an inexpensive one, e.g. the one priced 2 euro-cent (which is quite insignificant in the programming package of eighty channels provided by large distributors), could save a large amount of money, particularly if the subscription fee remains unaltered, as it is usually the case. 
Cable distributors may earn large profits through additional programme packages, the so called "pay" services ${ }^{5}$, charged separately. In this case, and only for these services, a distributor pays the rebroadcasting rights to television stations according to the number of subscribers. It remains unknown, however, whether distributors charge these costs to all subscribers, by including them in the price of basic subscription. It is therefore difficult to estimate the amount of profit earned from services of this type.

Considering the fact that the leading operators have "divided" the market, it is difficult to talk about real competition. There are very few towns where consumers have an opportunity to choose between two or more providers; each provider is a monopolist in their territory, free to set and raise the price of their services and is not obliged to account for their quality ${ }^{6}$. Although the general structure of the cable package is similar amongst most providers, the prices of radio and television programme distribution vary from city to city, i.e. depending on the operator. The number of available channels also varies. To compare, the table below illustrates the prices of these services in several countries in the region (Table 4).

Table 4. Prices of cable operators' services in some European countries (in EUR)

\begin{tabular}{|c|c|c|c|c|}
\hline Country & Operator & $\begin{array}{c}\text { Number of } \\
\text { channels } \\
\text { (basic choice } \\
\text { of } \\
\text { programmes) }\end{array}$ & Price & $\begin{array}{c}\text { Average } \\
\text { price per } \\
\text { channel }\end{array}$ \\
\hline Slovenia & UPC Telemach & 54 & 16.27 & 0.30 \\
\hline Croatia & B.net & 41 & 10 & 0.24 \\
\hline Romania & RCS & 66 & 8 & 0.27 \\
\hline Bulgaria & Cable Tel & 73 & 10 & 0.14 \\
& Bulsatkom & 43 & 6.5 & 0.15 \\
& Centrum Group & 76 & 12 & 0.16 \\
\hline Bosnia and & HS & 44 & 6.5 & 0.15 \\
Herzegovina & Elob Catv & 40 & 6 & 0.15 \\
& BiH Cabel Net & 46 & 6 & 0.13 \\
\hline Hungary & Fibernet & 59 & 23 & 0.39 \\
& UPC & 55 & 22 & 0.40 \\
& T-com & 46 & 20 & 0.43 \\
\hline Serbia & SBB & 77 & 8 & 0.10 \\
\hline
\end{tabular}

5 The Pay TV service provides additional channels to its subscribers, classified in packages according to their contents. The interested subscribers have the opportunity to choose a particular package (or packages) of channels and pay separate fee for it.

6 The SBB company is an exception, as it needs the approval by the Republic Broadcasting Agency to raise the prices. 
Although the fee price of 8 EUR, charged by the SBB, is considered high for citizens, it is the lowest amount when compared to other countries, taking into consideration the greatest and most diverse choice of programmes. In addition, for instance, USA citizens pay 18.08 USD on average per month for the basic cable programming comprising the average of 44.6 channels, which is 0.27 EUR per channel, when converted.

\section{Choice of programmes}

Although there is not a single regulation in the field of cable distribution to impose an obligation on operators to establish their choice of programmes taking into consideration their contents it still has to meet a variety of citizens' needs.

By establishing the content of the media based on the choice of programmes, cable operators, as well as programme broadcasters, are in a position to influence the public through their editorial policy, which means that they have considerable responsibility in this respect. Managers of these companies say that the choice of programmes only depends on how much it is attractive to the viewers. This criterion, however, should not be the only one. The cable distributors' programme related policy should take other principles of the content of the media into consideration, such as diversity and equal distribution of programme formats.

In their previous practice, operators in Serbia have only been oriented towards increasing the number of channels, without any serious selection in their choice. It is different in developed countries, which, although having at disposal the technical possibilities to increase the number of radio and television stations in their package, do not consider this to be their primary objective. They pay more attention to promoting their company as a brand in the media environment, choosing more diverse radio and television channels of better quality, focusing on requests of their consumers for special programmes. Due to such a policy, it becomes important to broadcasters which provider will rebroadcast them and whether it is reputable among viewers. A good example of such policy is a German cable operator called Unitymedia, which includes a satellite channel for children KidsCO in its package, explaining this step in the following broadcaster statement: By including the KidsCO channel in the children's package, the company Unitymedia recognised KidsCO as a safe and responsible environment for children and our channel fits perfectly into their choice of quality channels.

The existing regulation in the field of cable distribution does not provide an opportunity to the civil sector to express, through the so called "open channels", the needs of non-profit organisations, citizens' associations, schools and other 
organisations, which would create a more favourable environment for communication of citizens, institutions and public departments ${ }^{7}$.

\section{Consumer Relations}

The Rules on Terms and Conditions for Radio and Television Programme Distribution and Contents of the Authorisation (2009, Article 17) ${ }^{8}$, hereinafter the Rules, specify the obligation for operators to provide, on their information channel or web site, all the necessary information to their subscribers. In addition, the Rules (Article 7) stipulate that the authorisation for radio and television programme distribution service provision has to include the information concerning the availability of data on tariffs, pricelist and standard contract. Despite the legal obligation, the majority of cable operators has not publicly published all the required data.

At this point, neither present nor future subscribers are informed on the cable operators' method of work: particularly whether they observe the Law on Consumer Protection and protect the personal information of their subscribers, what will be in the court's jurisdiction in case of disputes, and whether particular programmes are going be temporarily scrambled for reasons of copyright protection. All this demonstrates the fact that the Republic Telecommunications Agency was more concerned about the protection of distributors and their rights, than the rights of subscribers.

\section{Service quality}

Consumers submit most complaints to cable distributors in respect of the technical quality of the delivered picture and sound. The Rules on Terms and Conditions of Distribution Service Provision stipulate the quality of service the programme distributor is required to provide to subscribers (Article 24). It also specifies that the distributor is obliged to provide that parameters pertaining to the quality of service provision be in compliance with international and domestic recommendations and standards. This condition does not mean much without the concretisation of these standards and recommendations, as their

7 Open channels appeared for the first time in the USA during the 70s of the previous century. They marked the beginning of a new penetration of civil society in the mass media complex. They were most popular in Germany, where the programme prepared by the citizens, is transmittable in the cable network. Citizens have at their disposal a studio for editing, including the professional television crew working there and providing all the necessary technical support. These programmes are financed from the radio and television subscription. One of the most popular such channels is Offener Kanal Berlin. Open channels add a new quality to freedom of communication, where citizens take an active part in the mass media communication.

Official Gazette of the Republic of Serbia, no. 95/2006. 
number is quite substantial. The text reads that a subjective grading of picture and sound quality may not be inferior to grade 4, according to the grading scale given under standards SRPS N.N6 134 and SRPS N.N6 135, which correspond to the International norms IEC 569 and IEC 543. However, it is specified in the description of these standards that they are used for the assessment of quality of the television and radio receiver, therefore, having a completely different purpose. They may only be used to indicate that a particular radio receiver or TV set is better or worse than the standard one. Consequently, based on the abovementioned standards, it is impossible to establish whether a subscriber has received a technically faulted signal from the operator, so they may not serve as the quality assessment criteria for the distributed picture and sound. Due to this oversight in the Rules, the technical quality of the delivered picture and sound remains undefined.

\section{Conclusion}

The process of telecommunications market liberalisation has been similar in all countries of the CEE region. The reason behind this may be found in their political and economic background and the fact that their economy was stateowned. The period of transition towards the market economy, involving Serbia along with Bosnia and Herzegovina, Croatia, Montenegro etc., is marked by harmonisation with the European Union regulations. On this path, practical experiences from Serbia are of great significance and may be useful to all the countries in which this process is underway.

Based on the information provided in the text, a conclusion may be drawn that, in order to achieve the efficient business operation of companies for radio and television programme distribution in market liberalisation circumstances, it is necessary that all stakeholders, i.e. the state, regulatory bodies and companies, focus on the following issues:

- Apart from telecommunications, the legal regulation should cover other fields related to this type of activity, such as: construction of network infrastructure and regulation of ownership of these facilities, consumer protection, personal information protection etc.

- Regulatory bodies should take equal care of the companies' interests on the one hand and consumer satisfaction on the other.

- Companies having a significant market share should be prevented from establishing a monopolistic position.

- The companies which succeed in attracting strategic partners and manage to access capital market may become powerful economic entities (for instance, the SBB company). 
- Cable operators have to be familiar with technology development and extend their range of services by including new services such as the Internet, satellite programme distribution, fixed network via distributive networks.

\section{References:}

Borgulya, A./Hahn, J. (2008): Work related values and attitudes in Central and Eastern Europe, in: Journal for East European Management Studies, 13,3, 216-238.

Bortz Media and Sports Group, Inc. (2008): An analysis of the cable industry's impact on the US economy. document via-Internet-available at the following web-site: http://www.ncta.com/DocumentBinary.aspx?id=743.

Byzalov, D. (2008): Unbundling cable television: An empirical investigation, document viaInternet-available at the following web-site: http:/groups.haas.berkeley.edu /marketing/sics/pdf/Byzalov.pdf.

Clark, E./Soulsby, A. (2009): Perceptions of MNC management: Local parent sensemaking in international joint venture process, in: Journal for East European Management Studies, 14,3, 286-309.

Group of authors. (1996): Kablovska televizija (Cable television), Beograd, JP RTS.

Harte, L.(ed.): Introduction to cable television (CATV): Analog and digital cable television and modems, 2nd Edition, Althos Publishing Inc.

Lazovic, S./Bogojevic, D./Raspopovic, V. (2003): Strategija razvoja kablovskih distribucionih sistema (A development strategy for cable distribution systems), in: Tehnika - Saobracaj, 50, 1,13-21.

Markovic, G. (2006): European telecommunication market liberalization and harmonization consequence on strategic positions of national operators, 14th Telecommunications Forum, TELFOR 2006, Belgrade, Serbia

Miletic, M. (2008): Resetovanje stvarnosti (Resetting Reality), Novi Sad, Protocol.

Radenkovic, V. (2008): Radio i televizijska produkcija (Radio and television production), Novi Sad, FTN.

RATEL. (2009): Pregled trzista telekomunikacija u Republici Srbiji u 2008. godini (A survey of the telecommunications market in the Republic of Serbia for the Year 2008.), Beograd.

Ratkovic Njegovan, B. (2007): Mediji i auditorijum (Media and their Audiences), in: Link, $58,6,23-26$.

Strategic Marketing/SMMRI and AGB Nielsen Media Research (2009): Istrazivanje gledanosti lokalnih TV stanica u Srbiji (Researching the viewership of Serbia's local TV-broadcasters).

Tintor, V.(ed.) (2009): Liberalization of the mobile telephony market in the Republic of Serbia, in: Technology in Society, 31, 4, 384-398. 